\title{
ПОВЫШЕНИЕ УСТОЙЧИВОСТИ ОТРАСЛИ ЗЕРНОПРОИЗВОДСТВА МОНГОЛИИ
}

\author{
Шаймерденова А.К \\ Казахский агротехнический университет им. С.Сейфуллина \\ г. Астана, Республика Казахстан
}

\section{РЕЗЮМЕ}

В связи с тем, что Монголия вступает в новую фазу развития, характеризуюшуюся глобализацией экономических отношений и возрастающей конкуренцией на мировом продовольственном рынке, в котором важная роль отводится зерновой отрасли, необходимым становится раскрытие сущности понятия устойчивости отрасли зернопроизводства и определение путей ее повымения.

В статье раскрывается понятие «устойчивости отрасли зернопроизводства». Разработаны рекомендации и предложения по ее повымению.

КЛЮЧЕВЫЕ СЛОВА: устойчивость, отрасль производства зерна, сельскохозяйственное производство, факторы производства, валовая продукция.

\section{ВВЕДЕНИЕ}

В аграрном секторе экономики Монголии произошел переход к многоукладной экономике в форме приватизации сельскохозяйственных перерабатывающих
заинтересованность сельхозтоваропроизводителей в развитии интеграции и кооперации, создании кооперативных форм собственности. Переход экономики на рыночные отношения создал качественно новые социально-экономические условия развития производства. В аграрном секторе Монголии, как и во всех постсоветских странах, была проведена приватизация земли и имущества, осуществлена реорганизация госхозов, созданы условия для развития рынка сельскохозяйственной продукции, сырья, конкуренции. Однако, проводимые реформы не создали равных условий для производителей и потребителей сельскохозяйственной продукции, рынок еще не стал регулятором межотраслевых пропорций, а свободное ценообразование углубило диспаритет цен на сельскохозяйственную продукцию, средства и предметы труда, поставляемые сельхозтоваро производителям промышленностью. Существующий рыночный механизм усилил тенденции присвоения значительной части чистого дохода, производимого сельским хозяйством, промышленностью, торговлей и другими отраслями общественного производства. В этой связи сократился платежеспособный спрос населения на продовольствие из-за снижения реальных доходов, что предопределило спад производства сельско хозяйственной продукции, обострило проблему неплатежей, оснащенности сельхозтоваро производителей, снижение эффективности и устойчивости сельскохозяйственного производства. Повышение устойчивости производства, способствует росту народного благосостояния, решению социальных задач, является необходимым условием не только повышения эффективности производства, но и полного удовлетворения потребности хозяйств в сырье и населения в продуктах питания. Развитие внешнеэкономических связей Монголии с зарубежными странами вызывает необходимость повышения устойчивости производства сельскохозяйственной продукции, так например зерна, имеет политическое значение и относится к престижу страны. В устойчивом производстве заинтересованы как производители, так и потребители, т.е. предприятия, перерабатывающие сельскохозяйственную продукцию. Сложность проблемы устойчивости состоит в том, что она имеет множество аспектов, каждый из которых характеризуется своими целями исследования, требует изучения. 


\section{МАТЕРИАЛЫ И МЕТОДЫ ИССЛЕДОВАНИЯ}

В процессе написания научной статьи была использованна частная методика. Частная методика конкретизирует общую методику для определенной отрасли в отношении определенных вопросов, поставленных для выполнения соответствующих задач.

При изучении экономической устойчивости отрасли зернопроизводства использованны статистические данные производства зерна Монголии. При обрабортке информации и представлении результатов применен стандартный пакет прогармм «Microsoft Word», «Microsoft Excel».

Основным источником информации, является статистический сборник Монголии, сведения о зернопроизводстве страны за 2000-2009гг. Основной задачей является - определение основных путей повышения устойчивости отрасли зернопроизводства Монголии.

\section{РЕЗУЛЬТАТЫ ИССЛЕДОВАНИЯ}

Термин «устойчивость» имеет ряд синонимов, раскрывающих с некоторой условностью суть явления, основой которого является «стабильность». Однако повышение устойчивости - это не стабилизация ее на достигнутом уровне, а неуклонный рост. В последнее время в результате становления рыночных отношений достаточно успешно завоевывает позицию понятие «конкурентоспособность». В смысловом плане, «устойчивость» можно характеризовать, как «равновесие» или «балансирование». Равновесие связано с устойчивостью, а балансирование - с постоянным воздействием и не может быть жестко фиксированным.

Понятие устойчивость производства сельскохозяйственной продукции сформировалось в конце XIX - начале XX века в статистических исследованиях Обухова В.М., Пасхавера И.С, Фортунатова А.Ф., Четверикова И.С. Они связали устойчивость урожая со снижением его колеблемости. В основу устойчивости, в исследованиях современных авторов, положена неравномерность поступления продукции сельского хозяйства по годам из-за большой зависимости урожая от специфических условий производства. Поэтому устойчивость на основе колебаний удобнее было бы рассчитывать по отдельным культурам на основе методов вариационной статистики.

Развитие производства зерна в дореволюционной период, рассматривал Б.С. Ястремский, он отмечает, что до отмены крепостного права земледелие носило застойный характер, и сопровождалось более низкой абсолютной и относительной колеблемостью урожайности, чем за период после отмены крепостного права, когда урожайность зерновых культур стала ускоренно возрастать. Однако, как уже отмечалось ранее, если производство не может быть устойчивым в каждом году, то оно должно быть устойчиво за ряд лет, причем эта устойчивость должна выражаться во взаимной компенсации положительных и отрицательных колебаний.

В большей части под устойчивостью экономисты понимают степень удовлетворения потребности сельскохозяйственного производства - «это наличие необходимой тенденции изучаемого статистического показателя, характеризующего сельскохозяйственное производство, с минимальным влиянием на него неблагоприятных условий при оптимальной экономической эффективности производства, обеспечивающее расширенное воспроизводство».

Под устойчивостью сельскохозяйственного производства понимается возможность системы нейтрализовать влияние негативного воздействия и обеспечить население продуктами в необходимых объемах и ассортименте. Согласно, распространенным в экономической теории представлениям, под устойчивостью обычно понимается «динамическое развитие в период устойчивого на протяжении достаточно длительного периода экономического роста».

Опыт стран с развитой рыночной экономикой показывает, что устойчивое производство зерна возможно только при использовании достижений научно-технического прогресса, в основе которого лежат инновационные процессы, позволяющие вести непрерывное обновление зерновой отрасли.

Таким образом, можно отметить, что устойчивость производства зерна - это производственный процесс, основанный на достижении научно-технического прогресса, сбалансированном воспроизводстве ресурсов, обеспечивающий достаточный уровень прибыли, соответствие рыночному спросу на зерно на уровне научно обоснованных норм потребления населением.

Устойчивое производство зерна служит важной составной частью налоговых поступлений в бюджет от переработки и реализации. Зерновой рынок включает в себя почти все элементы рыночных отношений. Поэтому, необходимо определить пути повышения устойчивости отрасли зернопроизводства Монголии с тем, чтобы в них оптимальным образом сочетались экономические стимулы, как к росту объемов производства, так и к повышению его устойчивости в каждом земледельческом хозяйстве. Производство зерна в Монголии традиционно является крупной отраслью растениеводства. 
Таблица 1

Структура растениеводства

\begin{tabular}{|c|c|c|c|c|c|c|c|c|c|c|}
\hline & 2000 & 2001 & 2002 & 2003 & 2004 & 2005 & 2006 & 2007 & 2008 & 2009 \\
\hline зерно & 142,1 & 142,2 & 125,9 & 165,0 & 138,4 & 75,5 & 138,6 & 114,8 & 212,9 & 391,7 \\
\hline пшеница & 138,7 & 138,7 & 123,1 & 160,4 & 135,6 & 73,5 & 127,8 & 109,6 & 209,8 & 388,1 \\
\hline картофель & 58,9 & 58,0 & 51,9 & 78,7 & 80,2 & 82,8 & 109,1 & 114,5 & 134,8 & 151,2 \\
\hline овощи & 44,0 & 44,5 & 39,7 & 59,6 & 49,2 & 64,1 & 70,4 & 76,4 & 78,6 & 78,0 \\
\hline итого & 383,7 & 383,4 & 340,6 & 463,7 & 403,4 & 295,9 & 445,9 & 415,3 & 636,1 & 1009,0 \\
\hline
\end{tabular}
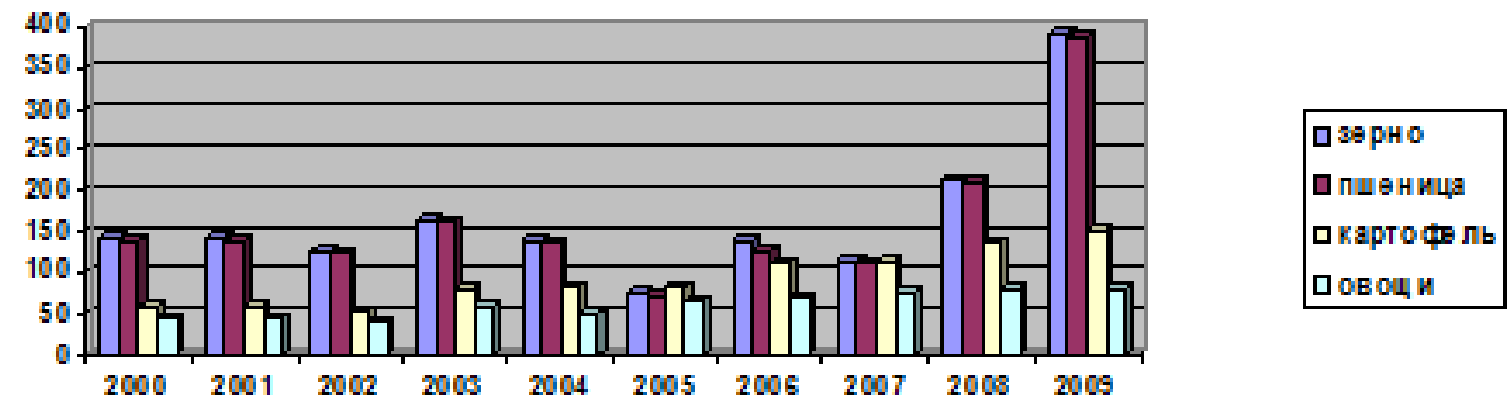

Рис. 1. Структура растениеводства

Как мы видим из таблицы 2, на долю зерна приходится около одной третьей стоимости валовой продукции растениеводства. Под зерновыми занята большая часть площади пашни, которая в наше время достигла 1 млн. га. Однако климатические условия Монголии определяют крайне сжатые сроки уборки зерновых и необходимость привлечения массы рабочих со стороны

Основные показатели производства зерна

Таблица 2

\begin{tabular}{llllll}
\hline Показатели & $\mathbf{2 0 0 5}$ & $\mathbf{2 0 0 6}$ & $\mathbf{2 0 0 7}$ & $\mathbf{2 0 0 8}$ & $\mathbf{2 0 0 9}$ \\
\hline Посевная площадь, тыс. га & 159,1 & 126,2 & 121,8 & 154,0 & 255,5 \\
Урожайность, цн & 4,7 & 10,8 & 9,4 & 14,0 & 15,9 \\
Валовый сбор, тыс.тн & 75,5 & 138,6 & 114,8 & 212,9 & 379,4 \\
\hline
\end{tabular}

Общая посевная площадь зерновых в стране непрерывно уменьшалась до 2007 года (121,8 тысяч га), а с 2008 года начала постепенно увеличиваться. Средняя урожайность за пять лет составляет 11 ц/га (таблица 2).

Для повышения устойчивости отрасли зернопроизводства Монголии необходимо принять следующие меры:

1. Осуществляемую государственную поддержку отрасли в виде кредитов, дотаций и правовой среды необходимо совершенствовать. Особое внимание при этом уделить на обеспечение высококачественными семенными материалами и создание системы страхования
2. Особенностью отрасли зернопроизводства в Монголии, как и всего земледелия в целом является сочетание экстенсивного и интенсивного методов, которые зависят от природноклиматических условий и достигнутого уровня развития. Это обуславливает необходимость применения новейших технологий производства и современного менеджмента.

3. Необходимо осуществить переход от малопроизводительного крестьянского хозяйства к современному фермерскому хозяйству. А для этого нужно совершенствовать законодательную и нормотивно-методическую базы, в частности, обеспечить продажу сельскохозяйственных угодий частным лицам. 
4. Опираясь на научно-технологические достижения и расширение орошаемых площадей, достичь повышения урожайности до уровня соседних стран.

\section{ВЫВОдЫ}

Таким образом, изучив мнение различных ученых, можно сделать вывод о том, что устойчивость - это производственный процесс, основанный на достижениях научно-технического прогресса, который обеспечивает рыночный механизм спроса на зерно, достаточный уровень прибыли для расширенного воспроизводства ресурсов и сохранения окружающей среды. Развитие научнотехнического прогресса позволяет нейтрализовать влияние негативных воздействий природноклиматических факторов и удовлетворять потребность в высококачественном зерне.
5. Совершенствовать механизмы организации размещения научных исследований и внедрять их результаты в производство.

\section{СПИСОК ИСПОЛЬЗОВАННОЙ ЛИТЕРАТУРЫ}

1. Монгол улсын статистикийн эмхтгэл 2003 (Статистический сборник Монголии), Уланбатор 2004г., с.131.

2. Монгол улсын статистикийн эмхтгэл 2007 (Статистический сборник Монголии), Уланбатор 2008г., с.197.

3. Монгол улсын статистикийн эмхтгэл 2009 (Статистический сборник Монголии), Уланбатор 2010г., с.192.

4. Зайгатов И.Б., Половинкин П.Д. Экономические проблемы повышения устойчивости сельскохозяйственного производства. - М.: Экономика, 1984.- 240с.

5. Николаев А.А., Пахно В.С. Устойчивость сельскохозяйственного производства и пути его повышения // Экономика сельскохозяйственных и перерабатывающих предприятий, 2001.-№4.-С. 1315. 